Bence Erika*

Ispánovics Csapó Julianna

Bölcsészettudományi Kar, Újvidék
UDC: 821.511.141.09(497.11)"19"

DOI: $10.19090 /$ gff.2020.2.247-268

Originalni naučni rad

\title{
KUNCZ ALADÁR FEKETE KOLOSTOR CÍMÜ REGÉNYE AZ ELSŐ VILÁGHÁBORÚT TEMATIZÁLÓ MAGYAR REGÉNYEK KONTEXTUSÁBAN**
}

\begin{abstract}
Kuncz Aladár 1931-ben megjelent Fekete kolostor címü regénye az első világháború eseményeit tematizáló irodalmi müvek második csoportjába, azoknak a regényeknek a körébe tartozik, amelyek az autentikus közelmúlt történelmi eseményeit az idő múlásával létrejött másfél évtizedes rálátási távlat perspektívájából ábrázolták. Ilyen értelemben az európai és a magyar irodalom kontextusában is vizsgálható és értelmezhető: feltárulnak megegyező, illetve az adott müfaji sortól elkülönülö és eltávolító vonásai. A korszak magyar irodalma vonzatkörében legtöbbször Markovits Rodion Szibériai garnizon (1928) és Aranyvonat (1929) címü regényeivel kerül összevetésre, míg a jugoszláviai/vajdasági magyar irodalomban - több más, kevésbé markáns, vagy csak részben első világháborús prózamű mellett - Darvas Gábor „Mindent meggondoltam és mindent megfontoltam..." (1930), Munk Artúr A nagy káder (1929) és Szabó István - Andrée Dezső: Egy legionista naplója (1931) címü regényei összefüggésében értelmezhető. A kutatás előfeltételezése, hogy a Fekete kolostor nagyobb részt eltér, s új regénysort kezdeményez a magyar irodalom alakulástörténetében: az internálótáborok világát megjelenítő magyar (tábor)regények sorába illeszkedik. A jelölt regénytípus-vonzatköreiben való vizsgálata ugyanakkor rámutat a korszak, a múlt század húszas éveinek végén kibontakozó irodalompolitikai erővonalak alakulására, illetve a kisebbségi irodalmak konstituálódásának szinkron folyamataira is. A dolgozat az összevető vizsgálatok eredményeit mutatja be.
\end{abstract}

Kulcsszavak: első világháború, (tábor)regény, rálátási távlat, magyar irodalom, kisebbségi irodalom.

\section{BEVEZETÉS}

1929-es könyvismertetőjében Schöpflin Aladár (Schöpflin 1929) hadifogolykönyveknek nevezi az évtized végén a világ- és a magyar irodalomban is

\footnotetext{
* erika.bence1967@gmail.com

** A tanulmány a Szerb Köztársaság Oktatás- és Tudományügyi Minisztériuma 178017. számú projektumának keretében készült.
} 
nagy számban megjelent háborús tematikájú regényeket; ezeknek azt a változatát, amely - mint az általa bemutatott két könyv, Markovits Rodion Aranyvonat (1929) és Munk Artúr A nagy káder (1929) címü müve - a fogolytáborokba hurcolt katonák sorsának és életének történeteit, eseményeit ábrázolja egyfajta kollektív emlékezeti kontextusban. Nem véletlen, hogy Markovits egy évvel korábban napvilágot látott és nagy sikert aratott regénye, a Szibériai garnizon a Kollektív riportregény alcímet kapta, hiszen megírásához a Keleti Újság felhívására jelentkezett több száz volt hadifogoly lágeremlékeit is felhasználta. Munk Artúr sem regénynek, hanem „feljegyzések”-nek minősíti müvét, amelynek szerzője egy „,pleni”, azaz fogoly ${ }^{1}$, tehát egy kényszerü kollektíva tagjaként, illetve élethelyzet átélőjeként láttatja az eseményeket. Schöpflin e regények keletkezéstörténeti (a későbbi értelmezések szerint: gadameri értelemben vett hermeneutikai) (Gadamer, 1984) szituációját illetően nagyrészt ugyanarra a következtetésekre jut, mint a jelenségre vonatkozó több évtizeddel későbbi kutatások ${ }^{2}$ :

„A Szibériai garnizon sorsa körülbelül azonos a Remarque könyvével. Mind a kettőnek rendkívüli sikere három tényezőből tevődött össze. Az első az anyag érdekessége, a másik az anyag tárgyalásának a tömegek számára rokonszenves, mindenki számára szemléletes módja, a harmadik a megjelenés pillanata, az a lélektani pillanat, amikor az emberekben, miután tíz évig undorodtak mindentől, ami a háborúra emlékeztette őket, egyszerre felébredt a kívánság, megtudni, hogy is volt a háború, mi volt az élete és sorsa a fronton és a fronton túl, a hadifogságban az egyszerü katonának. Ma aztán a háborúról szóló regények özöne uralkodik a könyvpiacon mindenütt, németek, franciák, angolok, amerikaiak versenyeznek a háborús könyvek írásában és kiadásában. Az emberiség nagy keresztrefeszíttetéséből irodalmi divat lett, amely egy ideig még virulni fog, aztán

\footnotetext{
${ }^{1}$ Hogy a ,pleni” az osztrák foglyok orosz neve, egy névvel és bibliográfiai adatokkal nem jelölt forrásból tünt elő számunkra: http://www.tanar.org.rs/wpcontent/uploads/2013/11/k101.pdf

2 „Mintegy tíz évnek kellett eltelnie ahhoz, hogy a figyelem egy másik nézőpontból is az első világháború élményanyaga felé forduljon. A húszas-harmincas évek fordulója egyébként Európában is a háborús irodalom nagy korszakának tekinthető: Remarque regénye, a Nyugaton a helyzet változatlan 1929-ben, Céline-é, az Utazás az éjszaka mélyére 1932-ben jelent meg. Markovits müvét 1928-ban adták ki, és ezzel itthon ő jegyezte az első hadifogoly-regényt. Munk Artúr A nagy káder címü, szintén elfelejtett regénye csak két évvel később, míg Kuncz Aladár Fekete kolostora 1931-ben jelent meg, Markovits tehát idehaza elsőként jelentkezett egy olyan témával, amely milliókat érintett: szinte minden családban akadt egy hadifogoly" (Hammerstein 2011). (Lásd még: Szekernyés 2011, Bence 2015, Bence 2018, Bence - Kocsis 2019).
} 
felváltja más divat $\mathrm{s}$ nem marad belőle egyéb, mint a belőle termett néhány maradandó becsü könyv" (Schöpflin, 1929).

Szekernyés János a Markovits-opus kiterjedéseit vizsgáló összefoglaló értékü tanulmányában hasonlóképp kontextualizálja a jelenséget:

Megjelenésekor, az 1920-as évek végén, amikorra immár nemzetközi szinten is beértek a világháború higgadt és hiteles mérlegre állításának feltételei, kétségbevonhatatlanul reális elvárást, sürgető korigényt elégített ki Markovits Rodion regénye [...] Igazából világviszonylatban is Markovits Rodion regénye, a Szibériai garnizon indította el a háborús irodalom második - őszintébb, szókimondóbb, humánusabb, józan szembenézésre és önvizsgálatra sarkalló szakaszát, amelyben aztán a divat szülte szokványos, semmitmondó divatmemoárok, propagandaírások mellett olyan nagy hatású, veretes remekmüvek születtek, mint Erich Maria Remarque Nyugaton a helyzet változatlan, Ludwig Renn Háború, Ernst Glaeser A 902-esek, Arnold Zweig Grisa szakaszvezető, Ernest Hemingway Búcsú a fegyverektől, Roland Dorgelès Fakeresztek. Kolozsvárott pedig 1931-ban hagyta el a nyomdát Kuncz Aladár fogolyregénye, a Fekete kolostor (Szekernyés, 2011: 68).

A korszakra irányuló kutatás a vajdasági magyar irodalomban is feltárta az első világháborús hadifogolykönyvek fentiekhez mérhető markáns vonulatát és szinkron jelenségeit, beleértve a sikerkönyvek utóéletének, a folytatás sikertelenségének történetét is (Bence 2015, Bence 2017, Bence 2017a, Bence 2018, Bence - Kocsis 2019). A sorból a Schöpflin Aladár által is bemutatott A nagy kádert, Munk Artúr első háborús tematikájú regényét, valamint folytatását $A$ hinterlandot (1933), Szabó István - Andreé Dezső Egy legionista naplója (1930), Darvas Gábor „Mindent megfontoltam és mindent meggondoltam...” (1930) címü müvét emelhetjük ki, illetve a történetet egy sajátos szempontból - a háborús poszttrauma hatását feltárva - elbeszélő Farkas Geiza-regényt, A fejnélküli embert (1933).

A hivatkozott vizsgálatok azt is egyértelmüvé teszik, hogy mind az európai, mind a magyar irodalomban létezik az első világháborús tematikájú prózamüveknek (naplók, visszaemlékezések, dokumentumregények etc.) egy első, a világháború lezárását követő éveket jelölő vonulata, azonban Jaroslav Hašek Švejk-történetein (Horváth 2017) kívül nemigen hagytak nyomot az irodalmak alakulástörténetében, nem elsősorban azért, mert dilettáns munkák, hanem mert megjelenésükkor még hiányzik mögülük az a befogadói igény és beleegyezés, azaz a komplex hermeneutikai pillanat, amely a második hullámban napvilágot látott múvek sikerét és hírnevét elősegítette; Dr. Bokor Ervin Menekülés a szibériai fogságból. Japánon és Anglián keresztül/Két magyar tiszt viszontagságai (1919) és Fleissig, József 
Szibériai napló. Fogságom és szökésem címü, 1920-ban megjelent könyvét említhetjük e kontextusban. 1919-ban Nagybecskereken is napvilágot látott egy könyv, Tarkó János Amíg a nagy vihar tombolt... címü regénye, amely tematizálja ugyan az első világháború eseményeit, de a reá vonatkozó referenciális, illetve összehasonlító vizsgálatok (Bence, 2017; Bence - Kocsis, 2019) arról tanúskodnak, hogy a Tarkó-regény (miként majd a második regényvonulatban Farkas Geiza $A$ fejnélküli ember címü müve) inkább a müfaji sortól való eltérés és elmozdulás jelenségét képviseli: romantikus elbeszélői hagyományokra ráíródó sci-fi regény.

1931-ben, tehát az ún. első világháborús regények második hullámának „kifutása” határán látott napvilágot Kuncz Aladár Fekete kolostor címü, némi pontatlansággal (hiszen a francia internáltság állapotáról szól) fogolyregénynek nevezett alkotása, amely rövid időre ismét dinamizálta az első világháború történetei iránti érdeklődést. Feltételezésünk szerint a regény megjelenése és kritikai fogadtatása irodalompolitikai erővonalak és szociológiai mozzanatok érvényességét is tükrözi a magyar irodalom aktuális korszakában. Épp ezért a regény korabeli és utóéleti recepcióját is figyelembe vesszük, illetve a vázolt keletkezéstörténeti szituációban, más művek összefüggésében vizsgáljuk jelentéseit!

\section{AKTUÁLIS RECEPCIÓ ÉS UTÓÉLET}

A Fekete kolostor kritikai fogadtatásának elismerő hangvételébe, az írói életmüvet felmagasztaló retorikába - a regény vitathatatlan esztétikai és intellektuális kvalitásai mellett -részben az író betegsége és halála is belejátszott. Korabeli források ${ }^{3}$ szerint Babits Mihály (Babits, 1931) Erdélyi Helikonban közölt kritikájának korrektúráját még olvasta az író, de a Nyugat decemberi számában megjelent méltatások ${ }^{4}$ már emlékező jellegüek: értelemszerüen nem fogalmaznak meg kritikai észrevételeket. A kegyeleti dimenziók mellett ugyanakkor arról is tanúskodik visszhangja, hogy egy másféle diskurzussal, például Markovits Rodion Szibériai garnizonjának zajos sikerével, illetve Markovits írói habitusával szemben a Nyugat és alkotói köre már régóta várt erre: a saját ízlésvilágának megfelelö, intellektuális karakterü, polgári-értelmiségi értékelveket képviselő első világháborús regényre. „Egyetlen hamis hangot, egyetlen gikszert, egyetlen

3 Molter Károly nyomán: Lighthouse. https://baloghpet.com/2009/12/31/kuncz-aladar/ (2020. június 10.). Uő. Kuncz Aladár. A magyar irodalom története. https://mek.oszk.hu/02200/02228/html/06/500.html

${ }^{4}$ Kosztolányi, 1931, Schöpflin, 1931 
magánérdekü részletet, pathétikus kisiklást, szentimentális giccset nem találtam. Minden komoly, egyszerü és igaz, egész a stílusig, a mondatokig" (Babits, 1931: 421) - állapítja meg Babits Mihály, miután ismertetőjében az ellenképet is megrajzolta:

A naiv dicsekvés és kéjelgő önbeszennyezés, lírai áradozás és felületes riportszerüség, fölös pátosz vagy cinikus könnyedség, kicsinyes dühök és hiúságok kielégítése és még hamisabb tárgyilagosság, unalmas részletezés vagy hatásos poéntirozás, érzelgős siránkozás vagy pózos szárazság: csupa olyan dolgok, amikből csak egy árnyalat is az egész mü szépségét és erejét tehette volna kérdésessé (Babits, 1931: 421) ${ }^{5}$.

Kosztolányi Dezső is az elbeszélöi attitüd erkölcsi imperatívuszát: „bölcseleti szerénység”-ét és ,intellektuális előkelőség”-ét hangsúlyozza írásában; (Babitshoz hasonlóan) elutasítva az első világháborút megjelenítő narratívák ideológiai elkötelezettségét a poétikai szempontokkal szemben: „Van benne valami erkölcsi szerénység, mely olyan, mint a lélek illata. Sohase tör pálcát senki fölött, sem népek, sem egyének fölött. Még rabtartóit se gyülöli. Téved, aki ezt a könyvet a franciák elleni vádiratnak tekinti” (Kosztolányi, 1931).

A posztumusz értékalkotói helyzet lehet az alapja a máskor meglehetősen objektív hangú kritikus, Schöpflin Aladár emelkedett/elragadtatott hangvételének is, s megállapításának, amelyben a keresztény polgári értékrend attribútumait emeli ki a regény világából - esztétikai és poétikai komponensek helyett:

A legkeresztényibb könyv a modern magyar irodalomban. Nem azért, mert tisztán érzett és tisztán ábrázolt vallási részletek vannak benne, mint az internáltak hajnali miséje a kis falusi templomban, szemben a kékruhás szelíd kis Mária-szoborral, nem azért, mert az író bensőséges eszmélkedésekkel próbálja öntudatossá tenni viszonyát a valláshoz. Az egésznek eszmei boltozata sajátképen keresztényi: a

${ }^{5}$ Babits Mihály véleményalkotása hátterében Markovits Rodion háborús regényei, a Szibériai garnizon (1928) és az Aranyvonat (1929) lelkes, világsikert jelentő fogadtatástól az elutasító, írói bukással egyenértékü recepciójának hangjai is felismerhetőek: az Aranyvonat elmarasztaló kritikai értékelését Schöpflin Aladár (Schöpflin, 1929) visszafogott, elsősorban a Szibériai garnizon elbeszélői előnyeire koncentráló bírálatától Molter Károly (Molter, 1930) éles kritikájáig. A kérdésben az utókor a korszak ízlésvitáját, ideológiai és (irodalom)politikai harcait is észrevételezi. A késői recepció már nem látja igazoltnak az Aranyvonat poétikai alulminősítését a Szibériai garnizonnal szemben, s az említett irodalmi és politikai tájékozódások, valamint az ,irodalomszociológiai viszonyok” (Baliga, 2014:121-122) megváltozását érzékeli a fordulatban. (L. még: Bence, 2018; Bence - Kocsis, 2019) 
legszebb keresztény illúziók egyikének, a szenvedésben való megigazulás eszméjének pillérére van felépítve (Schöpflin, 1931) ${ }^{6}$.

A Fekete kolostor kritikai értékelésének szempontjait Németh Andor a személyes látószög és megéltség élményével gazdagítja, hiszen nemcsak írótársa és barátja volt Kuncz Aladárnak, de az internáltságban is fogolytársa. Amellett, hogy a regény történeteinek és jeleneteinek referenciális vonatkozásait is ismeri és feltárja, kifejti azokat a lelki és intellektuális folyamatokat, illetve beállítottságokat, amelyek jelen vannak a regény háttérvilágában, közremüködtek létrejöttében. A mü szerinte is - felfokozott kritikai fogadtatását és sikerét az utóbbi mozzanattal, a személyes és az emberi narratíva jelentőségével magyarázza:

Legélesebben látó múbírálóinkat is zavarba hozta a Fekete kolostor példátlan közönségsikere. A tökélyre ritkán reagálnak ilyen közvetlenül, ilyen tüntető elismeréssel a tömegek. Amivel nem azt akarom mondani, hogy a Fekete kolostor nem igazi müremek. De a rajongás, amellyel olvassák s beszélnek róla, több a tökéletes munkának kijáró elismerésnél. A meghatottsággal vegyes áhítat, mely olvasóin elmaradhatatlanul erőt vesz, a megpillantott embernek szól, aki ezzel a könyvével felfedte volt magát (Németh, 1933).

A korabeli ízlésvita, valamint elvi nézetkülönbségek érvényesülésére mutat rá Hammerstein Judit is, amikor Markovits-tanulmányában - nem véletlenül - a Kuncz-opus kanonizáltságát emeli ki ellenpéldaként:

A két regény sorsa ugyanakkor arról is tanúskodik, hogy a Kuncz által képviselt értelmiségi élményanyag eleve értékesebbnek, időállóbbnak ítéltetett, mint a Markovits-féle plebejus narratíva. Ez pedig arra is rávilágít, hogy az irodalmi

\footnotetext{
${ }^{6}$ Külön, a jelenségre irányuló alapos kutatások fényében tehetnénk csak bármilyen releváns észrevételt Schöpflinnek a regény ,keresztény” mivoltára vonatkozó kijelentésére, de valószínüsíthető, hogy maga az értékrend és perspektívája összefügg a Nyugat és köre szociológiai tájékozódásával, frekventált alkotói magatartásaival és ízlésével. Közvetve, talán, a Markovits Rodion képviselte „,plebejus” és asszimiláns zsidó habitus és értékrendre vonatkozó allúzió is rejlik benne. Markovits haszid zsidó családból származott, s noha törekvéseit tekintve az urbánus értelmiség körébe tartozott, távol állt tőle az az arisztokratikus kifinomultság, amelyet Kuncz magatartásában észrevételeznek és dicsérnek kritikusai: „Kuncz Aladár a háború kitörésekor huszonnyolcéves fiatalember, hivatására nézve író, foglalkozására nézve tanár, rajongója az életnek, az irodalomnak, a napnyugati müveltségnek. Nyaranta, ha szerét teheti, francia földre zarándokol. Monoklit hord a szeme szögletében s a kor divatja szerint krizantémet a gomblyukában. Régi, párizsi kávéházakban szeret üldögélni ürömpálinkája előtt, új költőket olvasgatva” (Kosztolányi, 1931). Mi több, sokan egyenesen nyers, faragatlan személyiségként írják le visszaemlékezéseikben (Kellér, 1978). (L. még: Bence, 2018a; Hammerstein 2011.)
} 
művek magyar kanonizációjában társadalmi, demokratikusnak aligha tekinthető megfontolások is közrejátszottak (Hammerstein, 2011).

Noha - főleg az emlékező hangvételü írások ${ }^{7}$ - megpróbálják olykor a feledésbe merült Kuncz-portrét is a köztudatba illeszteni, e törekvésnek nincsenek reális alapjai, még akkor sem, ha egy irodalmi remek vagy életmü kanonizáltságának felső értékei nehezen állapíthatók meg, illetve mindig lehetnek olyan szegmensei, amelyek értelmezési szempontból kiaknázatlanok maradtak.

Az első világháború kitörésének és eseményeinek centenáriuma a kérdést, illetve a jelenséget tematizáló regényeket, naplókat és emlékiratokat is újfent a figyelem középpontjába állította. Ez az aktualizáció a Fekete kolostort is érintette. Az EX Symposion 2015-ben Kuncz Aladár-emlékszámmal kapcsolódott a jelenséghez (EX Symposion, 90. szám), de a folyóirat 2013/4-es, Együtt, 1914 címü tematikus számában (EX Symposion, 84. szám) is szerepel Józsa Márta Kuncz Aladárról szóló esszéje (Józsa, 2013). Ez utóbbi szerző Kuncz Aladár ,jelenidejüségé”-re vonatkozó megállapítására reflektál Cseke Péter, amikor cikkében (Cseke, 2018) áttekinti az elmúlt évszázad Kuncz-recepcióját, kezdve Jancsó Elemér (1905-1971) irodalomtörténész törekvéseitől ${ }^{8}$ a forrás-, a referenciális és a monografikus kutatásokon (Lőrinczi László, Jeney Éva kutatásai és vizsgálatai a helyszínen, Pomogáts Béla 1968-as monográfiája) át az emlékállítás manifesztációjáig (emléktábla-avatás Noirmoutier-ban) kíséri végig a történéseket (Bágyoni Szabó, 1973; Józsa, 2013; Cseke, 2018). Ennek nyomán egyértelmüvé válik, hogy a Fekete kolostor (referenciális) tereit érintő utazások és vizsgálatok Kuncz Aladárnak a helyszínre történő visszatérésétől (Jeney, 2015²), illetve

\footnotetext{
${ }^{7}$ Bágyoni Szabó István 1973-ban közölt írásában utal a hatvanas években „még akkor elég ritkán emlegetett Kuncz Aladár írásmüvészetére” (Bágyoni Szabó, 1973, 1664). Józsa Márta az Ex-Symposion I. világháborús emlékszámában: „Ennek az árvaságnak az okai valószínúleg értéksemlegesek, és ott keresendők, hogy a mü kilóg a háborús regények sorából, amennyiben nem a háború hősiességéből és pusztításából, szenvedésből és felemelkedésből épülő katarzisából építkezik. Aztán: szerzője egykötetesnek tekinthető erdélyi író, akinek lehetősége és ideje sem volt bent tartania müvét az irodalmi fősodorban, hiszen a megjelenése után azonnal meghalt. Jelentőségét, modernitását, értékállóságát soha senki nem vonta kétségbe. Kerek évfordulókkor akadnak méltatói, az emléktábláját már fölavatták Noirmoutier-ban, a fekete kolostornál, de kutatója alig adódik; idézettsége, recepciója pedig gyakorlatilag nincs" (Józsa, 2013).

${ }^{8}$ Bágyoni Szabó, 1973, 1664.

9 „Kuncz leveleiből kiderül, hogy készült Franciaországba, sőt járt is még ott...” (Jeney, 2015. 7.)
} 
testvérbátyja, dr. Kuncz Ödön ${ }^{10}$ odautazásától kezdve a mai napig aktuálisak: Lőrinczi László (1919-2011) négy évtizeden át, több korszak- és kutatási modell ${ }^{11}$ keretében kutatta a(z) (élet)mü referenciáit, amelynek eredménye a három kiadást megért Utazás a Fekete kolostorhoz (1975) címü riportkönyve, illetve szépirodalmi tematizáció (A szökés, dráma, 1986) is füződik a nevéhez. Jeney Éva több tanulmány és beszámoló formájában tette közé a Kuncz-regény helyszínein és levéltárakban végzett, a mü referenciális vonatkozásait érintő kutatásainak eredményeit (Jeney 2013, 2014, 2014a, 2015). Ezeknek konzekvenciái arra mutatnak, hogy az író, noha a Fekete kolostor narratívája megtörtént eseményeken alapul, a referenciálist a fiktívvel ötvöző természetszerü poétikai eljárások révén - a krónika és a riport eszköztárának következetes érvényesítése helyett - egy nagyarányú regénykompozíció és szuverén regényvilág megalkotására törekedett regényírás közben, ezért a Fekete kolostor elsősorban szépirodalom és nem dokumentum.

A jelölt kutatások (Lőrinczi, 1973, 2011; Filep, 2015; Jeney, 2013, 2014, 2014a, 2015) kimeneteként az is nyilvánvalóvá vált, hogy a Kuncz-opus referenciális vizsgálata is lezárulóban van, helyét mindinkább a komparatív, illetve a hatáskutatások veszik át. A valóságnak való megfeleltetés helyett azok a kutatások lehetnek most már inkább fontosak, amelyek az első világháborús narratívák sorában (vagy soraiban), a hasonlóságok és a különbözőségek ötvözetében láttatják Kuncz Aladár múvét: az elmozdulásokra, illetve a narratívaalkotó tendenciákra koncentrálnak.

${ }^{10}$ Vö. 7-8.

${ }^{11}$ „Az Utazás a Fekete kolostorhoz három kiadásában Lőrinczi kutatásainak három fázisa különböztethető meg, illetve fonódik egybe: a) az ihletforrás és a mü viszonyának a tisztázása; b) a regény szereplőinek a felkutatása; c) a remekmü kultúrdiplomáciai szolgálata. [...].Első útja esetlegesen alakult, ám a primér élményszerzés mély nyomokat hagyott benne. Ezért is nevezi »érzelmes utazásnak « ezt a látogatást. Ennek alapján a másodikra már tudatosan készült. Abból indult ki, amiből Babits is: „A Fekete kolostor nem egyszerü memoár: napló-érték, de regény-érték is egyben. Nemcsak a tábor eseményeinek krónikája, hanem egy lélek belső fejlődésének drámai története." Ezért aztán az Utazás a Fekete kolostorhoz nyomozásait is úgy olvashatjuk, mint egy »detektívregényt «, vagyis az oknyomozó riport és az esszé határvidékén született alkotást, amelyik »gyönyörü búvópataka« a »sorsoknak és szimbólumoknak«. Maga a szerző szerényen »irodalomtörténeti riport«-nak nevezi a munkát, és ezen a halála évében megjelent harmadik kiadásban sem akart változtatni, bár meggyőződése lehetett, hogy négy évtizeden át voltaképpen egy mikrofilológiailag megalapozott monográfiához hordta a Jancsó Elemér által igényelt »alapköveket« (Lörinczi, s.d., Cseke, 2018). 


\section{A FEKETE KOLOSTOR AZ ELSŐ VILÁGHÁBORÚS MAGYAR REGÉNYEK SORÁBAN}

A „feljegyzések” mint a regény jellegére, létrejöttére és élményalapjára mutató meghatározás nemcsak a Kuncz-regény, hanem Munk Artúr A nagy káderének alcímében is szerepel: Egy pleni feljegyzései a forradalmi Oroszországból. Az idegenség létállapotát Kuncznál az internáltság (a regényben a boche mint a német személy pejoratív értelmű megnevezése), az utóbbinál a pleni (az osztrák fogoly gúnyneve) jelöli. Bokor Ervin háborús emlékiratainak címe, Menekülés a szibériai fogságból. Japánon és Anglián keresztül/Két magyar tiszt viszontagságai (Bokor, 1919) már eleve tartalmazza a kirekesztettségre és a fogolylétre utaló argumentumokat, miként Fleissig József munkája is: Szibériai napló. Fogságom és szökésem (Fleissig, 1920).

Munk második regénye, A hinterland: A mögöttes országrész háborúja (1933) is egyértelmüen besorolható a háborús regények sorába. Ugyanakkor néhány, az első világháború eseményeit tematizáló regény címében csak reflexív, vagy metaforikus módon van jelen ez az információ. Darvas Gábor naplóregényének címe: „Mindent meggondoltam és mindent megfontoltam...” (Darvas, 1930), Ferenc József császár háborús kiáltványának legismertebb mondatát parafrazálja (Anonim, 1914), míg Markovits Rodion második, ugyancsak az első világháborút tematizáló regénye címébe (Aranyvonat) az oroszországi impériumváltás egyik ismert szimbólumát, a kincstári aranyat elszállító vonat nevét emeli be ${ }^{12}$. Viszont nem tud (vagy csak elvétve) a recepció a Szabó István - Andrée Dezső jegyezte Egy legionista naplója címü kalandregényről (egy dilógia első része, a második kötet: Hat esztendö a Francia Idegenlégióban: Szabó - Andrée 1930), amelynek utolsó két, Világháború, illetve Orosz hadifogságban című

\footnotetext{
12 „Markovits Rodion 1884. július 15-én született Kisgércén és 1948. augusztus 27-én hunyt el Temesvárott. Marosvásárhelyen és Budapesten jogot tanult. Az első világháborúban orosz hadifogságba került. Belépett a Vörös Hadseregbe és harcolt az orosz polgárháborúban. A világhírü író, Jaroslav Hašek mellett tagja volt az I. Nemzetközi Brigádnak, amely bolsevik utasításra egy aranyvonaton [az ,első aranyvonat”: vasúti szerelvény az orosz polgárháborúból - B. E. megj.] elszállította a köztársaság [valójában: a cári nemzeti bank B. E. megj.] aranyát. A két író valószínüleg személyes kapcsolatban állhatott egymással [elterjedtebb vélemény szerint: soha nem találkoztak - B. E. megj.] krasznojarszki tartózkodásuk ideje alatt, mégis egymástól függetlenül írták meg világháborús nagyregényeiket: Hašek a Švejket, Markovits pedig 1927-ben a Szibériai garnizont. Érdekesség, hogy Markovits a keresztnevét Dosztojevszkij Bün és bünhödés címü regénye főhősének neve után vette fel”' (Baliga, 2014: 121, Bence, 2018: 46)
} 
fejezeteiben 67 oldalon, vagyis kisregény terjedelemben beszéli el az én-elbeszélő első világháborús kalandjait, köztük fogságba kerülésének viszontagságait is.

Szabó Istvánról nincsenek információink. Az Andrée Dezsőről szóló lexikonszócikkekből (Kalapis, 2002; Gerold, 2014), illetve a regényröl íródott korabeli kritikából (Csuka 1931) annyit szürhetni le, hogy Andrée 1926-ban egy párizsi újságírótanfolyamon találkozott a volt idegenlégiós katonával, (a feltételezhetően: újvidéki) Szabó Istvánnal, akinek „nyers feljegyzései” (Csuka, 1931: 27) képezik a négy évvel később napvilágot látott kétkötetes légiós kalandregény alapját. Ezeknek az adatoknak azonban nincs forrásjelölése, nem tudjuk, honnan származnak, ezért még az a kétely is felmerülhet bennünk, hogy az eredeti napló kitaláció, a regény fiktív terének része; miként a magyar irodalom évszázadai során erre számos példa adódott. Az viszont ismert adat, hogy Andrée teljesített valamilyen katonai szolgálatot az első világháborúban (Kalapis 2002), de nem tudjuk, hogy az Egy legionista naplója utolsó két fejezetének élményanyaga, a galíciai frontesemények, a Dubnónál történt fogságba kerülés, a Dnyeper menti fogolytáborokban való sínylődés, az onnan való szökés eseményei, a Jekatyerinoszlávban (ma: Dnyepropetrovszk), illetve a Fekete-tenger partján elterülő városokban való kalandozások, majd a hazafelé vezető út viszontagságainak (a vörös és a fehér rémuralom megtapasztalásának) ábrázolása és leírása Szabó, Andrée vagy mások személyes élményeiből táplálkozik-e, de rendkívül életszerünek tünik, mi több, a regény korábbi fejezeteinek elbeszélői hangjához képest változás áll be, megtörik hangvételének jellege és stílusa: sokkal összeszedettebb, kiforrottabb beszédmód jellemzi ezeket a fejezeteket. Minden bizonnyal „meredek” következtetés lenne azt feltételezni, miszerint ezek alapja nem Szabó, hanem Andrée személyes megtapasztalása, ugyanakkor későbbi fejezetek (pl. a Hat esztendö a Francia Idegenlégióban, 1923-1929 azon részei, amelyekben az elbeszélő a sivatagi élet lélekölö és devianciákat kiváltó hatásáról elmélkedik) is eredményeznek hasonló stílustöréseket: inkább egy müvelt és a tudományokban jártas író/szerkesztő, mintsem egy kalandor katona gondolkodását tükrözik. Az sem elhanyagolható mozzanat, hogy 1930-ban Andrée már ismerhette és olvashatta nemcsak Jaroslav Hašek Švejkjét (1923), hanem Markovits Rodion mindkét regényét, illetve Munk Artúr $A$ nagy káder címü müvét is. Több korábbi vizsgálat (Bence, 2015 2017b; Bence - Kocsis, 2019) mutatott rá a Markovits - Munk Szabó/Andreé-regények közötti összefüggésekre: hasonlóságokat elsősorban a galíciai fronton történtek ábrázolásában, a tisztikar felkészületlenségéröl és a háborús propaganda hatásáról alkotott (negatív) kép természetében ismerve fel. 
A Fekete kolostor és az Egy legionista naplója közötti analógia - minthogy a Kuncz-regény cselekménye nem a fronton játszódik - más módon és szempontok szerint mutatkozik meg. Az utóbbi főhősét is - elbeszélése szerint Franciaországban, Belfort városában éri az első világháború kitörésének és a hadüzenetnek a híre: miként Kuncz naplóírója, az Egy legionista naplójának énelbeszélöje is a helyi lakosság kitörő lelkesedéséröl és az idegenek (különösen Németország és Ausztria-Magyarország polgárai) iránti ellenszenvéről, sőt ellenséges magatartásáról számol be:

Útban hazafelé minduntalan meg kell állnunk, tüntető menetek vonulnak végig az utcákon. Civilek és katonák lelkesedéstől kipirult arccal énekelnek, szinte extázisban éltetik a háborút és a hadsereget. Nem messze a kocsiktól újabb tüntető felvonulással találkozunk, a sor elején meglepődve ismerem fel jóbarátunkat, a szomszéd asztalost. A menetből izgatott kiáltások hallatszanak, nem éppen hízelgő vonatkozással Németországra és Ausztria-Magyarországra (Szabó - Andrée, 1930: 206).

Az ő látószöge és képalkotási készsége azonban más társadalmi alapokon nyugszik: noha polgári-hivatalnok családból származik, eleinte ennek megfelelő neveltetésben részesül, ám szökései miatt már kora tizenéves korában kikerül saját kulturális közegének hatása alól: kalandvágytól hajtva elöször 13 évesen szökik meg hazulról (mint kiskorú személyt a rendőrség viszi vissza a szülői házba), hogy három évvel később (beleértve első világháborús katonáskodását és az oroszországi fogságot is) nyolc évre, majd kis megszakítással (mert a háború után a határok átjárhatatlansága miatt kénytelen néhány évig otthon, azaz Újvidéken tartózkodni) végérvényesen a kalandorok és csavargók útjára lépjen. Viszontagságos utazása, otthontalan vándorlása és hánykódása során elsősorban a társadalom alsóbb néprétegeivel kerül kapcsolatba, mi több, befogadásra és családra a vándor cigányok között talál, noha megjegyzi, hogy ezekben az országokban, azaz Spanyolországban és Franciaországban a cigányok helyzete sem annyira alávetett és kilátástalan, mint hazájában, vagyis Magyarországon. Elbeszélése szerint épp ezeknek a kisembereknek a jóindulata révén és segítségével sikerül még idejében Svájcba távoznia, miáltal megmenekül az internálástól - ugyanakkor Budapestre érve (hogy ne nyilvánítsák katonaszökevénynek) kénytelen jelentkezni frontszolgálatra. Így kerül először kiképzésre Kolozsvárra, majd a galíciai frontra. A regénynek ez az elbeszélésrétege olyan tapasztalatokat és felismeréseket is magában foglal, amelyeket Kuncz Aladárnak társadalmi helyzete, habitusa és elszigeteltsége miatt nem volt lehetősége sem átélni, sem megszerezni. Amíg Kunczban végig egy ideális kép él Magyarországról és a magyar társadalomról (s ez 
nem változik meg a regény megírásának idejében, tehát az eseményeket követően kialakult több mint egy évtizedet jelentő rálátási távlatból sem), addig Szabó István és Andrée Dezső emlékiratainak/kalandregényeinek én-elbeszélője már az események aktuális idejének kezdetén megsejti, el tudja képzelni a másik oldal valóságképét is:

Arra gondolok, hogy Németországban, Ausztriában és Magyarországban most épp így tüntetnek Franciaország ellen. Bizonyára ott is akadnak magamfajta messzi vándorok, akiket francia hazájuktól oda sodort az élet. Bizonyára nékik is vannak jólelkü szomszédaik, mint itt nekem és nem éreznek haragot az idegen pajtással szemben, akinek most hirtelen el kell indulnia.

Ha azok, akik ma szerte a világban egymás ellen tüntetnek, mind ismernék egymást úgy, mint például az asztalos szomszéd meg én, a tüntetés helyett vajon nem nyújtanák-e egymásnak a kezüket barátságos kiengesztelődéssel... (Szabó Andrée, 1930: 207).

Miközben Kuncz mesélője végig a beérkező magyarországi hírek, elsősorban levelek és hírlapcikkek alapján tájékozódik a háború valóságáról és kimenetéről, illetve elutasítja a francia forrásokból származó tényanyag hitelességét, addig Darvas Gábor, Munk Artúr, Markovits Rodion és (feltehetően) a Szabó István - Andrée Dezső szerzőpáros is saját harctéri és hadifogolyélményeiből meríti elbeszélt, lejegyzett, ábrázolt anyagát. Nem véletlen, hogy regényeikben, akár kívülálló, akár én-elbeszélő közvetíti (jegyzi fel) számunkra a történéseket, nagyon hamar bekövetkezik a katartikus ráébredés pillanata, amikor a háborús propaganda által közvetített valóságmodellben felismerik a hazugságot, saját léthelyzetükben a megtévesztettség állapotát (Markovitson kívül ugyanis valamennyien önként, meggyőződéssel jelentkeztek katonának), s hangjuk lelkesedésből átvált iróniába, sőt, szarkazmusba. Különösen erős ez a tendencia Munk Artúr 1933-as regényében, A hinterlandban, illetve Darvas Gábornak a fikciót a valósággal az irodalmi mü természetéből következően ötvöző, de alapjaiban mégis személyes élményanyagra épülő naplóregényében. Nemcsak elbeszélőjét helyezi a szerbiai hadszíntérre, a tífuszkórházba, majd az Albánián át visszavonuló szerb hadsereg által magukkal vonszolt hadifoglyok helyébe, hanem maga is átélte ezeket a szörnyüségeket. Amikor a 20-as évek végén regénnyé formálja élményeit (autentikus naplójegyzeteit), már ebből a perspektívából indít, és a narratíva kimenete is keserü iróniába torkollik: „Eleinte csak egy kis kirándulási kalandnak számított az egész. Olyan nagygyakorlatfélének. Csak amikor az első halottak véres hulláján ültünk $\mathrm{s}$ a sebesültek kínos jajveszékelését hallgattuk, ébredtünk fel. Hohó, itt mégsem vaktöltéssel lövöldöznek" (Darvas, 1930: 5, Bence, 
2017a: 111). A regény egyik főhőse, a gépészmérnök Mayer Gyurka, akiben Darvas feltehetően saját alteregóját formázta meg, az Egy legionista naplója elbeszélőjének véleményéhez nagyon hasonló konzekvenciákat von le a háború kiváltó okait illetően:

Mit tudtunk mi akkor idegen népekröl, kisebbségekröl, expanzióról, nagyhatalmi törekvésekröl, imperializmusról, megsértett nemzetközi jogról, revanche-ról, vagy hasonlókról. Egy olyan éra neveltjei voltunk, akik csak saját magukkal törődtünk s akik anyanyelvükön kívül egy szót sem tudtunk (Darvas, 1930: 9; Bence, 2017a: 112).

S bár ezek a megállapítások (a tájékozatlanság és az egynyelvüség) a kozmopolita és múvelt Darvas Gáborra, Munk Artúrra és Andrée Dezsőre, miképp Markovits Rodionra sem érvényesek; nagyon is képesek beleélni magukat és megérteni a fentiekben jellemzett kisember, sőt, az alsóbb néprétegek gondolkodását és élethelyzeteit. S noha az is igaz, hogy az egyetemes európai kultúra iránt rajongó, kifejezetten frankofil Kuncz Aladár kulturális tájékozottságához és humánus kvalitásaihoz sem férhet kétség, társadalmi korlátai és habitusa - minden valószínüséggel - olykor megakadályozzák abban, hogy bizonyos helyzetekkel és plebejus érzésekkel azonosulni tudjon. Például értetlenül áll s némi pejoratív érvénnyel beszél a narrátor azokról az internáltakról (valójában foglyok, mint ő maga is), akik a vágyott szabadulás reményében beállnak katonának a Monarchia (azaz Magyarország) háborús ellenfeleinek soraiba (pl. a cseh származású Jeroszlav, dr. Herz pártfogoltja). Hasonló megítélésről beszélhetünk miután hazatért az orosz/szovjet fogságból orosz feleséggel az oldalán - Munk Artúr személyét illetően, kommunistagyanús elemnek számított, miként a recepció (Hammerstein, 2011; Szekernyés, 2011; Baliga, 2014) a legújabb kutatások fényében arról is említést tesz, miszerint Markovits Rodion Aranyvonat címü regényének - a Szibériai garnizon zajos világhírét követő - látványos bukása a harmincas évek elején nem annyira irodalompoétikai és esztétikai hiányosságokkal, mint inkább az irodalomszociológiai (Baliga 2014) körülmények megváltozásával magyarázható: a városi, s bizonyos értelemben asszimiláns törekvésü, de ortodox zsidó gyökereit soha meg nem tagadó ${ }^{13}$ Markovits Rodion, a Vörös Hadsereg volt katonája ebben az időben már származása, nyers modora és extrém magatartása miatt (szerencsejátékos szenvedélyfüggő, fittyet hány a polgári viselkedéskódexre, faragatlan és megbotránkoztató) nemkívánatos elem mainstream irodalmi és

13 Miként azt 1939-es novelláskötete, a Reb Áncsli és más avasi zsidókról szóló széphistóriák (Markovits, 2014) is jól mutatja. 
közéleti körökben. Ráadásul épp a Kolozsvárra visszatérő, ott irodalomszervező, parnasszien magatartású Kuncz Aladárral lesz nézeteltérése (Pomogáts, 1968). Ugyanakkor mind Markovits, mind Munk regényei, mind pedig az Egy legionista naplója vonatkozó fejezetei életszerüen mutatják be nemcsak azt a valóságot, miszerint a „pleni”-nek nemigen volt - ha túl akarta élni - sem a cári hadsereg, sem a vörösök fogságában más választása, mint hogy beáll soraikba, de azokat a nyilván túlontúl leegyszerüsített, de belülröl fakadó - plebejus életérzéseket is érzékletesen kifejezik, amelyek egy ilyen döntés mögött állhatnak a kisember szempontjából.

Az irodalom létformájáról szóló modern, nem hierarchikus és nem szubsztancialista szempontok értelmében egy jelenség mibenlétét és értékét megjelenésének aktuális kontextusában értékelhetjük; jelentőségét is az az értékkomponens határozhatja meg, amit saját korában ad hozzá (vagy nem) az irodalom alakulástörténetéhez (Gadamer, 1984). Kuncz Aladár regényének poétikai kvalitásai és irodalomtörténeti jelentősége kilenc évtized távlatából is megkérdőjelezhetetlen premisszákat jelöl, ugyanakkor a regény néhány jelentésmozzanatát másként, vagy árnyaltabb összefüggésben értelmezzük. Sajátos módon, ma épp azt tarthatjuk a regény kevésbé hatásos eljárásának, amit kortárs kritikusai dicsértek benne: az internálótábor monotóniájának cizellált leírását, ami pszichológiai értelemben nagyon is kifejező módon érzékelteti a szabadságában és mozgásterében korlátozott ember lelkiállapotát, ugyanakkor egy idő után egysíkúvá válik $^{14}$. Másrészt épp azt hiányoljuk a történetből - amennyiben az első világháborús regények sorában elemezzük -, ami dinamikussá, olykor eposzivá vagy groteszkké növeli amazok beszédmódját: a megtévesztett kisember túlélésért folytatott elkeseredett/hősies küzdelmének (csatákban, lövészárkokban), a hazugságra, a megtévesztettségre vagy az árulásra való ráébredés katartikus

\footnotetext{
14 Természetesen nem vonjuk kétségbe a miénktől eltérőn vélemények létjogosultságát sem, csak a kontextusba helyezés és az összehasonlítás érvényességét vitatjuk. Nem véletlen, hogy az opus kutatóiban rendre felmerül, hogy vajon maradéktalanul értelmezhetö-e a Fekete kolostor az első világháborús regények sorában:

És irodalmat szervezett, ami Trianon után egyedi feladat volt: az erdélyi irodalmat nem csak megszervezni kellett, ki is kellett találni. A Fekete kolostor 1931-ben jelent meg, Kuncz Aladár már a halálos ágyán feküdt, és ott olvasta az első recepciót, Babits Mihály az Erdélyi Helikonnak írt kritikáját. A Nyugat is azonnal reagált: Kosztolányi és Schöpflin Aladár méltatta a könyvet, amely akkor és azóta is a magyar irodalom egyik nagy árvája volt és maradt. Ennek az árvaságnak az okai valószínüleg értéksemlegesek, és ott keresendők, hogy a mü kilóg a háborús regények sorából, amennyiben nem a háború hősiességéből és pusztításából, szenvedésből és felemelkedésből épülő katarzisából építkezik (Józsa, 2013).
} 
pillanatainak (pl. A hinterland kórház-, a „Mindent meggondoltam...” vagy a Szibériai garnizon csatajeleneteiben) leírását, a közvetlen életveszély rettenetének, a bajtársak elvesztése miatt érzett döbbenetének, szenvedésének és fájdalmának plasztikus ábrázolását. S igaz ugyan, hogy Kuncz színes és jól kidolgozott társadalmi tablót állít elénk, s egy új (mini)társadalom kialakulását festi le előttünk az internálótábor falai között, azonban végig ragaszkodik egy, az adott korlátok között már érvényét vesztett normarend, így a társadalmi osztályok közötti különbség, a rögzült szerepek fenn- és megtartásához ${ }^{15}$. Ezzel szemben az oroszországi/szibériai fogolytáborok (A nagy káder, Szibériai garnizon, Aranyvonat, Egy legionista naplója), a szerbiai tífuszkórházak, lakatlan szigeteken müködő internáló-/fogolytáborok (,Mindent meggondoltam...”) világában, a hátország szélhámosainak korrupt, hierarchikus rendjében, a vesztett csaták utáni fejvesztett, kaotikus menekülésben (A hinterland, Egy legionista naplója) ezek a viszonyok szinte automatice bomlanak fel, fordulnak visszájukra, csapnak át ellentétes jelentésbe. Például Darvas Gábor, aki a szerbiai fronton teljesített szolgálatot, esett fogságba, betegedett meg tífuszban és került kórházba, szörnyűséges körülmények közé, majd csodával határos felépülését követően a visszavonuló szerb hadsereg hurcolja magával Albánia hegyein keresztül, elképzelhetetlen szenvedések közepette, naplójában meggyőződéssel vallja, hogy alacsony sorból származó, de jó felfogású, becsületes, bátor és rátermett legénye nélkül nem élte volna túl a megpróbáltatásokat. A társadalmi szokások és rend felbomlásának, a születéssel vagy a társadalmi ranggal nyert kiváltságok elértéktelenedésének legemlékezetesebb képe azonban az a jelenet Darvas regényében, amikor az albániai hegyek sártengerében, a végsőkig kimerült, éh- és szomjhalál tizedelte, félholtan vánszorgó, vagy a megpróbáltatások közepette eszüket vesztett hadifoglyok és semmivel sem, vagy alig jobb helyzetben levő fogvatartóik, a szerb katonák szétzüllött csoportjai között váratlanul felbukkan a

15 Számára az internáltság nem a nagyhatalmak küzdelméről, frontok állásáról és erőviszonyok alakulásáról szól az Atlanti-óceán francia partja mentén fekvő szigeten kialakított internálótáborban, ahol osztrákokkal, románokkal, németekkel, szerbekkel, csehekkel együtt várják a történelem végét, vagy legalábbis alakulását. Az ő életformaváltása, és annak alapos, dokumentált és értő leírása a polgári életforma örök időkre való eltünését jelenti - és ezt a kortárs olvasók is érzékelték. Kosztolányi együttérzően kiemeli nem a regény, hanem a szerző kapcsán -, hogy bizony, faragatlan emberekkel is vegyülnie kellett az internáltságban. Ez a fajta „mobilitás”, a korábbi társadalmi státusok teljes keveredése, felbomlása akkor még döbbenetet okozott. (Józsa 2013, 2014) 
gyalogosan, fejvesztve menekülő szerb király alakja, szürrealisztikus, lázálomszerü kép benyomását keltve a szemlélőben.

Regényét Darvas Gábor keserü iróniával zárja, reflektálva a szállóigévé lett császári mondat igazságtartalmára: „Legalább az a két minden ne lett volna benne.” (Darvas 1930. 280). A Fekete kolostor eredeti kézirata is dehonesztáló megjegyzéssel zárult, amely a szerzo//elbeszélő által képzelt és éltetett „szellemi” Magyarország és polgári társadalom (Trianonnal történt) végleges eltünését konstatálja. Ugyanakkor azok az első világháborús regények (a Szibériai garnizon, az Aranyvonat, A nagy káder, A hinterland, az Egy legionista naplója etc.), amelyeknek kontextusában vizsgáltuk a Fekete kolostort még ennél a messzebbre mennek: mindenkori létezését is kétségbe vonják.

\section{ÖSSZEGZÉS}

Fekete irodalom címü tanulmányában a Kuncz Aladár-kutató Jeney Éva (Jeney 2013a) (mindkét mű szempontjából) kétségbe vonja a Szibériai garnizon és a Fekete kolostor azonos müfajtípus keretében történő összehasonlíthatóságának érvényességét. A korábbiakban kifejtett, a Kuncz-regényt első világháborús magyar regények kontextusába helyező vizsgálatunk is hasonló eredményekre vezetett. Az azonos narratívaként való értelmezés ugyanis mind az említett háborús regények, mind a Fekete kolostor szempontjából felemás eredményekhez vezetnek: a Szibériai garnizon vagy A nagy káder a Kuncz-regény perspektívájából kisebb müvészi erejü teljesítményként hathatnak, míg fordított látószögből a Fekete kolostor az érdektelenebb és hatástalanabb kompozíció. Nem beszélve arról, hogy ha az aktuális keletkezéstörténeti szempontokat és az autentikus narratív összefüggéseket figyelmen kívül hagyjuk, akkor a Darvas-regény, vagy az Egy legionista naplója (amely szándéka szerint a korszak populáris irodalmi regisztereit igyekszik megszólaltatni) nagyrészt sikertelen, vagy dilettáns vállalkozásnak is tünhetnek. Holott nincs közük ahhoz a müvészregény-látásmódhoz és -kompozícióhoz, amelynek eljárásait és eszköztárát viszont a Kuncz-regény érvényesíti.

A bevezetőben említett regények közül - sajátos módon - legközelebb a kevésbé ismert, müvészi kvalitásaiban is messze eltérő amplitúdókkal rendelkező Amíg a nagy vihar tombolt... címü Tarkó János-regényhez áll, egyrészt, mert ez utóbbit is (címének kissé megtévesztő jellege miatt) pozitivista szemléletek könnyedén besorolhatónak látták az első világháborús regények sorába, másrészt mert - az egyébként Jókai Mór és Jules Verne sci-fi regényeinek hatására mutató (Bence, 2017) - regény szereplői (köztük egy múvészi hajlamú magyar mérnök), akik a háborús események hatására (noha néhányan kényszeredetten), mégis önként 
vonulnak ki a társadalomból, s egy földalatti barlangrendszerben alternatív és ideális (mini)társadalmat próbálnak kiépíteni, amelyhez a nagy háború franciaországi eseményei csak háttérként, kulisszaként szolgálnak, müködőképességét azonban mégis a külső világ jelenségeinek beszüremkedése és hatása teszi kétségessé.

A Tarkó-regénynek azonban még annyi köze sincs az első világháborúról szóló narratívákhoz, mint a Fekete kolostornak, nemcsak azért, mert Tarkó Jánosnak nem voltak személyes tapasztalatai sem a katonáskodásról, sem semmilyen internáltságról (a marne-i csatáról szóló regénybeli részletek tényanyaga hírlapi tudósításokból származhat), de eredeti elképzelései szerint sem háborús regénynek, hanem egyfajta államutópiának szánta alkotását. Regénye cselekményét azonban - a korszak müveltségi tájkép-elképzelése értelmében - ugyancsak francia és haladó társadalmi nézeteket valló, de polgáriasult nemesi környezetbe helyezi, s mert közvetlen tapasztalatai nem voltak róla - Kuncz Aladárral ellentétben - nem is ábrándul ki belőle, $\mathrm{s}$ ezáltal nem is mérséklődik frankofil rajongása, de - közvetlen háborús élmények hiányában - saját nemzeti létének szellemi tágasságáról és kvalitásairól alkotott ideái sem fordulnak ellentétükbe, mint történik az Markovits Rodion, Munk Artúr vagy Darvas Gábor esetében.

Hammerstein Judit az első világháborút tematizáló magyar regények sorában Munk Artúr A hinterland címü regényét vizsgálva mutat rá a vonatkozó kutatás lehetséges - eddig kevésbé vizsgált - kapcsolódási pontjaira, többek között Tersánszky Józsi Jenő A viszontlátásra drága... (1916) és A margarétás dal (1929) címü müveire (Hammerstein, 2017). Kuncz Aladár Fekete kolostor címü táborregényének vizsgálata szempontjából viszont ez az irány a háborús regények köréből való kiemelés és egy új kontextualizáció lehetőségét, a kutatás távlatait jelenti.

Erika Bence - Julijana Išpanovič-Čapo

ROMAN ALADARA KUNCA FEKETE KOLOSTOR [CRNI MANASTIR] U KONTEKSTU MAĐARSKOG ROMANA SA TEMATIKOM PRVOG SVETSKOG RATA

Rezime

Roman Aladara Kunca Fekete kolostor [Crni manastir] objavljen 1931. godine spada u drugu grupu književnih dela koja se bave tematikom događaja Prvog svetskog rata, među romanima koji prikazuju nedavne autentične istorijske događaje iz perspektive jedne i po decenije. U tom smislu se takođe može istraživati i tumačiti u kontekstu evropske i 
mađarske književnosti: otkrivaju se sličnosti romana kao i odlike koje ga izdvajaju iz date žanrovske grupe. U oblasti mađarske književnosti tog perioda, on se najčešće upoređuje sa romanima Rodiona Markoviča Szibériai garnizon [Sibirski garnizon] (1928) i Aranyvonat [Zlatni voz] (1929), dok se u jugoslovenskoj/vojvođanskoj mađarskoj književnosti - pored nekoliko drugih, manje istaknutih romana ili proznih dela koja samo delimično obrađuju tematiku Prvog svetskog rata - može tumačiti u odnosu na roman Gabora Darvaša „Mindent meggondoltam és mindent megfontoltam... “ [,,Sve sam promislio i sve razmotrio... “] (1930), A nagy káder [Veliki kadar] (1929) Artura Munka i Egy legionista naplója [Dnevnik jednog legionara] (1931) Ištvana Szaboa-Andrea Dežea. Pretpostavka istraživanja jeste da se Crni manastir uglavnom razlikuje od ostalih i pokreće novi niz romana $\mathrm{u}$ istoriji mađarske književnosti: uklapa se u seriju mađarskih logorskih romana koji prikazuju svet (internističkih) logora. $U$ isto vreme, ispitivanje pomenute vrste romana ukazuje na razvoj književnopolitičkih pravaca moći koji su se razvijali krajem dvadesetih godina prošlog veka, odnosno na sinhrone procese stvaranja manjinskih književnosti. Rad predstavlja rezultate ovih uporednih istraživanja.

Ključne reči: Prvi svetski rat, (internistički) roman, vremenska perspektiva, mađarska književnost, manjinska književnost.

\section{ALADÁR KUNCZ'S NOVEL FEKETE KOLOSTOR [THE BLACK MONASTERY] IN THE CONTEXT OF HUNGARIAN FICTION THEMES TACKLING THE FIRST WORLD WAR}

\section{Summary}

Aladár Kuncz's novel The Black Monastery, published in 1931, belongs to the second group of literary works thematizing the events of the First World War, among the novels that depicted recent authentic historical events from the standpoint of a one-and-a-half-decade perspective. In this sense, the novel can also be examined and interpreted in the context of the European and Hungarian literature: what is revealed are their similarities, as well as characteristics that separate and remove them from the given genre line.In the field of the Hungarian literature of the period, The Black Monastery is most often compared to Rodion Markovits's novels Szibériai garnizon [Siberian Garrison] (1928) and Aranyvonat [Golden Train] (1929), while in the Hungarian literature in Yugoslavia / Vojvodina - in addition to several other, less pronounced, or only partially World-War-I prose works. Namely, it can be interpreted in relation to Gábor Darvas's novel "Mindent meggondoltam és mindent megfontoltam..." ["I thought about everything and considered everything..."] (1930), Artúr Munk's A nagy káder [The Great Cadre] (1929) and István Szabó-Dezső Andrée's Egy legionista naplója [The Diary of a Legionnaire] (1931). The presumption of the research is that The Black Monastery differssignificantly and it initiates a new series of novels in the history of the Hungarian literature: it fits into the series of Hungarian (interning camp) novels depicting the world of (interning) camps. At the same time, the examination of the 
above-mentioned novel type in the topical sphere points to the development of the literary political lines of power that unfolded in the late twenties of the last century, and the synchronous processes of constructing minority literatures. The paper presents the results of these comparative studies.

Keywords: World War I, (interning camp) novel, perspective, the Hungarian literature, minority literature

\section{KIADÁSOK}

Darvas, G. (1930). „Mindent megfontoltam és mindent meggondoltam...” Novi Sad: Uránia.

Kuncz A. (1931). Fekete kolostor. Feljegyzések a francia internáltságból. Kolozsvár: Erdélyi Szépmíves Céh.

Markovits, R. [1928] (1986). Szibériai garnizon. Kollektív riportregény. Boldizsár Iván: Híres könyv - elfelejtett szerző. 5-6. Dr. Végh Oszkárné: Utószó. 454-458. Budapest: Ifjúsági Lap- és Könyvkiadó Vállalat.

Markovits, R. (1929). Aranyvonat. Budapest: Genius kiadás.

Munk, A. 1930. A nagy káder. Egy pleni feljegyzései a forradalmi Oroszországból. Budapest: Pantheon Kiadás.

Szabó I. - Andrée D. [1931]: Egy legionista naplója. Hat esztendö a Francia Idegenlégióban (1923-1929). Eredeti naplójegyzetek alapján sajtó alá rendezte: Andrée Dezső. Novi Sad: Uránia

\section{IRODALOM}

Anonim (1914): Megüzenték a háborút! Népszava. https://nepszava.hu/1028557_ mindent-megfontoltam-es-meggondoltam (2020. augusztus 1.)

Babits, M. (1931). Fekete kolostor. Erdélyi Helikon, 6. 419-421. (2020. június 10.)

Bágyoni Szabó, I. (1973). Kuncz Aladár-emlékek. Korunk, 11, 1664-1673. http://epa.oszk.hu/00400/00458/00437/pdf/EPA00458_Korunk_1973_11_1 664-1673.pdf (2019. 12. 4.)

Baliga, V. L. (2014). Egy szibériai tartalékos zászlós mindennapjai. Markovits Rodion: Aranyvonat. Pro Minoritate 121-123. www.prominoritate.hu/ folyoiratok/2014/ProMino-1402-beliv-09-baliga.pdf (2017. dec. 19.)

Bokor, E., Dr. (1919). Menekülés a szibériai fogságból. Japánon és Anglián keresztül/Két magyar tiszt viszontagságai. Budapest: Franklin-Társulat Magyar Irod. Intézet és Könyvnyomda. 
Bence, E. (2015). Az első világháború tematizációja az 1930-as évek vajdasági magyar irodalmában. In Virtuális irodalomtörténet. 102-113. Veszprém: Iskolakultúra.

Bence, E. (2017): Sci-fi a háborúban (Tarkó János: Amíg a nagy vihar tombolt...). In Miért sír Szulimán? Elemzések, bírálatok a magyar irodalom köréböl. 85-102. Budapest: Cédrus Müvészeti Alapítvány-Napkút Kiadó.

Bence, E. (2017a). Napló(regény) az első világháborúból. Darvas Gábor: „Mindent meggondoltam és mindent megfontoltam..." In Miért sír Szulimán? Elemzések, bírálatok a magyar irodalom köréböl. 103-117. Budapest: Cédrus Mủvészeti Alapítvány-Napkút Kiadó.

Bence, E. (2017b). Egy legionista a háborúban. Szabó István-Andrée Dezső: Egy legionista naplója. Hat esztendő a Francia Idegenlégióban (1923-1929). In Miért sír Szulimán? Elemzések, bírálatok a magyar irodalom köréböl. 117145. Budapest: Cédrus Mủvészeti Alapítvány-Napkút Kiadó.

Bence, E. (2018). Magyar bestsellerek, irodalmi (világ)sikerek a két világháború között. In Utazások Posztmonarchiában. Kulturális kontextusok. Elemzések, bírálatok a magyar irodalom köréböl. Szabadka: Életjel, 45-61.

Bence, E. (2018a). Ahogy egy életmú újraolvassa önmagát. Markovits Rodion: Reb Áncsli és más avasi zsidókról szóló széphistóriák In Utazások Posztmonarchiában. Kulturális kontextusok. Elemzések, bírálatok a magyar irodalom köréböl. Szabadka: Életjel 61-69.

Bence, E. - Kocsis, L. (2019). Memoires, Diaries, Diary Novels about the First World War in Haungarian Literature. Stredoeurópske pohl'ady. (1): 1. 8694.

Cseke, P. (2018). Zarándoklatok a Fekete kolostorhoz, avagy egy remekmü kultúrdiplomáciai szolgálata. Helikon, $24 . \quad$ (758.) https://www.helikon.ro/zarandokutak-a-fekete-kolostorhoz-avagy-egyremekmu-kulturdiplomaciai-szolgalata/

Csuka, Z. (1931). Szabó-Andrée: Egy legionista naplója. Mi Irodalmunk, 1931. augusztus 2. 27-28)

Farkas, G. (1933). A fejnélküli ember. Szabadka: Kalangya Könyvek.

Filep, T. G. (2015). Távol Párizstól. Ex Symposion. Kuncz Aladár-szám. 2015. 90, 1-5. http://exsymposion.hu/data/pdf_issue/2015_kuncz-aladar_simicharles_.pdf (2019. 12. 4.)

Fleissig, J. (1920). Szibériai napló. Fogságom és szökésem. Budapest: Benkő Gyula cs. és kir. Könyvkereskedése. 
Gadamer, H. G. (1984). Igazság és módszer. Egy filozófiai hermeneutika vázlata. Fordította: Bonyhai Gábor. Budapest: Gondolat.

Gerold, L. (2014). Vajdasági magyar irodalmi lexikon (1918-2014). Újvidék: Forum Könyvkiadó.

Hammerstein, J. (2011). Egy elfelejtett magyar világirodalmi bestseller (Markovits Rodion: Szibériai garnizon). Látó 22 (6): http://www.lato.ro/article.php/Egy-elfelejtett-magyar-világirodalmibestseller-Markovits-Rodion-Szibériai-garnizon/2092/ (2017. dec. 19.)

Hammerstein, J. (2017). A hátország szélhámosai. Kortárs, 7-8. 161-165. http://epa.niif.hu/00300/00381/00227/pdf/EPA00381_kortars_2017_07-08_161165.pdfHašek, J. [1923] (s. d) Švejk, a derék katona kalandjai a világháborúban. Ford. Réz Ádám. http://dydudu.hu/konyv/regeny/ hasek/svejk/ (2018. jan. 17.)

Horváth, Cs. (2017). A kimaradás módozatai. Kuncz Aladár: Fekete kolostor, Jaroslav Hašek: Švejk, egy derék katona kalandjai a világháborúban. IN Kappanyos András szerk. E nagy tivornyán. Budapest: MTA Bölcsészettudományi Kutatóközpont. 91-101.

Jeney, É. (2013). Beszámoló. Kuncz Aladár franciaországi emlékezethelyei. http://www.balassiintezet.hu/attachments/article/562/Kuncz\%20Aladar\%20 franciaorszagi\%20emlekezethelyei\%20(Jeney\%20Eva).pdf

Jeney, É. (2014). A megosztó és a megosztható múlt. Feljegyzések a francia internálásról, Pro Minoritate, XIV. évfolyam, 2. szám, 23-48.

Jeney É. (2014a). Fekete irodalom. Literatura 60 (1): 28-43.

http://www.balassikiado.hu/BB/NET/LITERATURA/Literatura_2014_1.pdf (2017. dec. 30.)

Jeney, É. (2015). Marginália a Fekete kolostorhoz. EX Symposion. Kuncz Aladárszám. 2015. 90, 6-13 (2019. 12. 4.)

Józsa, M. (2013). A boche. Kuncz Aladárról. EX Symposion. Együtt, 1914. 4. https://exsymposion.hu/index.php?tbid=article_page_surfer\&csa=load_art icle\&rw_code=jozsa-boche_3359

Józsa, M. (2014). A boche. Józsa Márta esszéje Kuncz Aladárról. Litera. hu (Első közlés: 2014. február 11.) https://litera.hu/irodalom/elso-kozles/a-bochejozsa-marta-esszeje-kuncz-aladarrol.html (2020. január 22.)

Kalapis, Z. (2002). Életrajzi kalauz, I. Újvidék: Forum Könyvkiadó, 41-42.

Kellér, A. (1978). Tökász. In Író a toronyban. Palásthy titka. Tökász. Zöld gyep, zöld asztal. A föispán. 181-217. Budapest: Szépirodalmi Könyvkiadó. 
Kosztolányi, D. (1931). Fekete kolostor. Kuncz Aladárról és könyvéről. Nyugat, 12. https://www.arcanum.hu/hu/online-kiadvanyok/Nyugat-nyugat-1908-1941FFFF0002/1931-2EC995/1931-12-szam-308696/figyelo468A96/kosztolanyi-dezso-fekete-kolostor-kuncz-aladarrol-es-konyverol478A96/ (2020. június 10.)

Lörinczi, L. (s. d.) Utazás a fekete kolostorhoz. Cseke Péter honlapja. https://sites.google.com/site/azidoharcokatujraz/home/2-szemelyeshaboruk/kuncz-aladar/lorinczi-laszlo-utazas-a-fekete-kolostorhoz (2019. 12. 4.)

Markovits, R. [1939] 2014. Reb Áncsli és más avasi zsidókról szóló széphistóriák. Reb Ancili şi alte povestioare despre evreimea oaşului. Schiller Erzsébet: Kisgércétöl a világhírig és vissza. 6-11. Ford. Felician Pop. Prefeță. 7-12. Kolozsvár-Cluj-Napoca: Kriterion Könyvkiadó-Editura Kriterion.

Molter, K. (1930). Markovits Rodion: Aranyvonat. Erdélyi Helikon 3 (1): 82-85.

Molter, K. (s. d.). Kuncz Aladár. A magyar irodalom története. https://mek.oszk.hu/02200/02228/html/06/500.html (2020. július 6.)

Munk, A. [1933] 1981. A hinterland. A mögöttes országrész háborúja. Bori Imre: Utószó. 235-243. Újvidék: Forum Könyvkiadó.

Németh, A. (1933). Emlékezés Kuncz Aladárról. Nyugat, 13-14. https://epa.oszk.hu/00000/00022/00560/17518.htm (2020. január 22.)

Pomogáts, B. (1968). Kuncz Aladár. Budapest: Akadémiai Kiadó.

Schöpflin, A. (1929). Hadifogoly-könyvek. Nyugat, 22-23. https://epa.oszk.hu/00000/00022/00479/14766.htm

Schöpflin, A. (1931). Fekete kolostor. Kuncz Aladárról és könyvéröl. Nyugat, 12. https://epa.oszk.hu/00000/00022/00516/16130.htm (2020. máj. 19.)

Szekernyés, János. 2011. Egy világsiker eredői, összetevői és utórezgései. Markovits Rodion és kollektív riportregénye a szibériai hadifogságról. Múlt és Jövö 26 (3): 51-73. www.multesjovo.hu/hu/aitdownloadablefiles/ download/aitfile/aitfile_id/1437/ (2017. dec. 19.

Tarkó, J. (1919). Amíg a nagy vihar tombolt... Nagybecskerek: Haász Testvérek. 